\title{
Thermodynamic properties of liquid alkali metals
}

\author{
P.B.Thakor, P.N.Gajjar, A.R.Jani \\ Department of Physics, Sardar Patel University, \\ Vallabh Vidyanagar-388120, Gujarat, India
}

Received September 18, 2000, in final form December 13, 2000

The internal energy, entropy and Helmholtz free energy of liquid alkali metals, viz. $\mathrm{Na}, \mathrm{K}, \mathrm{Rb}$ and $\mathrm{Cs}$ are investigated using pseudopotential perturbation scheme based on Gibbs-Bogoliubov variational technique. A local pseudopotential is applied to describe the electron-ion interaction in the liquid alkali metals. To introduce the exchange and correlation effects, the local field correction function proposed by Taylor is employed. The computed values for internal energy, entropy and Helmholtz free energy for the liquid alkali metals are in excellent agreement with the experimental data.

Key words: internal energy, entropy, Helmholtz free energy, pseudopotential

PACS: $65.50,71.15 . H$

\section{Introduction}

The Gibbs-Bogoliubov variational approach to investigating the thermodynamic properties of liquid alkali metals using pseudopotentials theory is well established and very effectively used in the past [1-13]. In such type of studies, one is concerned with choosing an appropriate reference system for the structure and the pseudopotential for electron-ion interactions. In all the above studies, people have used hard sphere (HS) [4-8] or one-component plasma (OCP) [9] or optimized random phase approximation [10] or charged hard sphere (CHS) $[11,12]$ or soft sphere (SS) $[13,14]$ as a reference system. For the electron-ion interactions they have employed either Ashcroft empty core model (AS) [15] or Heine-Abarenkov model (HA) [16] or Harmonic model potential (HMP) [17] or Generalized nonlocal model potential (GNMP) [13] or energy independent nonlocal model potential (EINMP) [7, 8]. Singh and Singh [4] have reported the thermodynamic properties of alkali metals at $373 \mathrm{~K}$ and noticed that for the alkali metals, the results of Helmholtz free energy due to AS model deviate from the experimental data $1.55 \%$ to $4.07 \%$. The outcome due to HA model gives $0.24 \%$ to $2.47 \%$ deviation from the experimental findings. In the case of HMP, this deviation is $6.62 \%$ to $14.65 \%$. They have employed hard-sphere 
reference system for structure contribution. In comparison to AS and HA model, the results due to HMP are poor. All such studies reveal that the accuracy of the results depends on the application of model potential. The different forms of the model potential have generated different values of the thermodynamic properties. Hence, we thought it worthwhile to investigate thermodynamic properties of alkalies using our model potential [18-20].

This paper deals with the computation of thermodynamic properties of liquid alkali metals $\mathrm{Na}, \mathrm{K}, \mathrm{Rb}$ and $\mathrm{Cs}$ at $373 \mathrm{~K}$ based on Gibbs-Bogoliubov (GB) variational technique. In the present work we choose the hard sphere reference system which provides analytical representation in term of single parameter, $\sigma$ known as hard sphere diameter $[21,22]$ and instead of working with historical model potentials like AS model and HA model, we have used our own single parametric model to describe electron-ion interaction [18-20].

The expression for our well established model potential in real space is [18-20],

$$
\begin{array}{rlrl}
V^{0}(r) & =0, & r<r_{\mathrm{c}} \\
& =-\left(\frac{2 Z}{r}\right)\left[1-\exp \left(\frac{-r}{r_{\mathrm{c}}}\right)\right], & & r \geqslant r_{\mathrm{c}} .
\end{array}
$$

The Fourier transform in reciprocal space is [18-20],

$$
V^{0}(q)=\left(\frac{-8 \pi Z}{\Omega q^{2}}\right)\left\{\cos \left(q r_{\mathrm{c}}\right)-\frac{q r_{\mathrm{c}} \exp (-1)}{1+q^{2} r_{\mathrm{c}}^{2}}\left[\sin \left(q r_{\mathrm{c}}\right)+q r_{\mathrm{c}} \cos \left(q r_{\mathrm{c}}\right)\right]\right\} .
$$

Here $Z, \Omega, q$ and $r_{\mathrm{c}}$ are the valency, atomic volume, wave vector and the potential parameter, respectively. The parameter $r_{\mathrm{c}}$ is evaluated using zero pressure condition. This method of determination of parameter is independent of any fitting procedure with the observed quantities. As parameter is determined with the zero pressure condition, it leads the system into the equilibrium position with minimum energy. This model potential is the modified version of the Ashcroft's empty core model. It is continuous in $r$ space. In comparison with the other historical model potential $[15,16]$ we have introduced some repulsive part outside the core which vanishes faster than only Coulomb potential $-Z e^{2} / r$ as $r \rightarrow \infty$. Moreover, it may be noted that the inclusion of this repulsive term outside the core makes the effective core smaller than the ionic radius of a free ion.

\section{Theory}

For the investigation of thermodynamic properties of liquid metals, the Helmholtz free energy, $F$, lies at the heart of the pseudopotential perturbation scheme. The standard thermodynamic relation for the free energy is [2-4]

$$
F=E-T S,
$$

where, $E$ is the internal energy and $S$ is the entropy of the system at a temperature $T$. 
Under the usual perturbation theory, the internal energy $E$ can be expressed as $[2-4]$,

$$
E=E_{\text {ion }}+E_{\text {elec }}+E_{\text {elec-ion }} .
$$

Here the first term $E_{\text {ion }}$ is composed of kinetic energy $\left\{(3 / 2) k_{\mathrm{B}} T\right\}$ of ions plus the contribution due to ion-ion interactions, usually known as Madelung contribution.

Thus, we write [2-4],

$$
E_{\text {ion }}=\left(\frac{3}{2}\right) k_{\mathrm{B}} T+\left(\frac{Z^{2}}{\pi}\right) \int_{0}^{\infty}\{a(q)-1\} \mathrm{d} q,
$$

where $Z$ is the valency and $a(q)$ is the structure factor. For the structure dependent contribution, the structure factor, $a(q)$, for liquid metals is calculated from the Percus-Yevick solution for hard sphere fluids which is characterized by the hard sphere diameter $(\sigma)$ or, equivalently, by the packing fraction $\eta=\left(\pi \sigma^{3} / 6 \Omega\right)$. Here we have considered $\eta=0.45$ as described by Ashcroft and Langreth $[21,22]$.

The term $E_{\text {elec }}$ in equation (2.2) is the energy of the homogeneous electron gas which is the sum of kinetic energy of electrons, exchange energy, correlation energy, and the low temperature specific heat contribution for the electron gas. Hence, the expression for $E_{\text {elec }}$ becomes [2-4]

$$
E_{\text {elec }}=N Z\left\{\left(\frac{3}{10}\right) k_{\mathrm{F}}^{2}-\left(\frac{3}{4 \pi}\right) k_{\mathrm{F}}-0.0474-0.0155 \ln k_{\mathrm{F}}-\left(\frac{1}{2}\right)\left(\frac{\pi k_{\mathrm{B}}}{k_{\mathrm{F}}}\right)^{2} T^{2}\right\}
$$

with $k_{\mathrm{F}}$ is the Fermi wave vector and $N$ is the total number of atoms.

In the framework of pseudopotential second ordered perturbation theory $E_{\text {elec-ion }}$ has been obtained by [2-4],

$$
E_{\text {elec-ion }}=\lim _{q \rightarrow 0}\left\{V^{0}(q)+\frac{8 \pi Z}{q^{2}}\right\}\left(\frac{Z}{\Omega}\right)+\frac{1}{16 \pi^{3}} \int_{0}^{\infty}\left\{V^{0}(q)\right\}^{2} a(q)\left\{\frac{1}{\varepsilon(q)}-1\right\} q^{4} \mathrm{~d} q,
$$

where, the first term on right hand side represents the first order energy and the second is the band structure energy. Here, $V^{0}(q)$ is bare ion pseudopotential and $\varepsilon(q)$ is the modified Hartree dielectric function [23]. $\varepsilon(q)$, which takes into account the conduction electrons interaction, is of the form

$$
\varepsilon(q)=1+\left\{\varepsilon_{\mathrm{H}}(q)-1\right\}\{1+G(q)\} .
$$

In this expression $\varepsilon_{\mathrm{H}}(q)$ is the Hartree dielectric function and $G(q)$ is the correction factor for the exchange and correlated motion of the conduction electrons. In the present study we consider the local field correction $G(q)$ due to Taylor [24].

$$
G(q)=\left(\frac{q^{2}}{4 k_{\mathrm{F}}^{2}}\right)\left[1+\frac{0.1534}{\pi k_{\mathrm{F}}}\right]
$$


Table 1. Input parameters used in the computation.

\begin{tabular}{|c|c|c|c|c|c|c|}
\hline Metal & $T(K)$ & $Z$ & $r_{\mathrm{c}}(\mathrm{au})$ & $\Omega(\mathrm{au})$ & $k_{\mathrm{F}}(\mathrm{au})$ & $\sigma(\mathrm{au})$ \\
\hline $\mathrm{Na}$ & 373 & 1 & 1.0729 & 277.932 & 0.4740 & 6.2046 \\
\hline $\mathrm{K}$ & 373 & 1 & 1.4408 & 535.332 & 0.3810 & 7.7199 \\
\hline $\mathrm{Rb}$ & 373 & 1 & 1.5747 & 656.168 & 0.3560 & 8.2618 \\
\hline $\mathrm{Cs}$ & 373 & 1 & 1.7474 & 830.565 & 0.3291 & 8.9370 \\
\hline
\end{tabular}

The second most essential part of investigating the free energy is the entropy, $S$, of the hard sphere fluids. Using the information of hard sphere diameter $(\sigma)$ or packing fraction $\eta$, one can evaluate the entropy, $S$, as [2-4].

$$
S=S_{\text {gas }}+S_{\eta}+S_{\text {elec }},
$$

with

$$
\begin{aligned}
S_{\text {gas }} & =\left(\frac{5}{2}\right) k_{\mathrm{B}}+k_{\mathrm{B}} \ln \left\{\Omega\left(\frac{k_{\mathrm{B}} T}{4 \pi}\right)^{\frac{1}{2}}\right\}, \\
S_{\eta} & =k_{\mathrm{B}} \eta(3 \eta-4)(1-\eta)^{-2}, \\
S_{\text {elec }} & =\left(\frac{\pi^{2} k_{\mathrm{B}}^{2} T}{k_{\mathrm{F}}^{2}}\right) .
\end{aligned}
$$

\section{Results and discussion}

We have calculated various contributions to the internal energy, entropy and Helmholtz free energy of $\mathrm{Na}, \mathrm{K}, \mathrm{Rb}$ and $\mathrm{Cs}$ at $373 \mathrm{~K}$. In expressions (2.3) and (2.5), the integration has been carried out up to $40 k_{\mathrm{F}}$ to avoid any artificial cutoff in the calculation and to achieve proper convergence. The input parameters used in present calculation are shown in table 1 .

The presently calculated values of internal energy, entropy and Helmholtz free energy are compared with experimental [25] as well as other theoretical data [4] in tables (2)-(4). Singh and Singh [4] have reported internal energy and entropy using AS model, HA model and HMP. In the case of Na reported data of Helmholtz free energy, there are deviations $4.07 \%, 2.47 \%$ and $6.62 \%$ due to AS model, HA model, HMP, respectively. For $\mathrm{K}$ these deviations are $4.02 \%, 0.24 \%$ and $9.08 \%$. For Rb $1.55 \%, 1.041 \%$ and $12.72 \%$ while for Cs these are $3.64 \%, 0.42 \%$ and $14.65 \%$.

The deviation of the Helmholtz free energy from the experimental values in the present study are $1.4 \%$ for $\mathrm{Na}, 0.41 \%$ for $\mathrm{K}, 0.71 \%$ for $\mathrm{Rb}$ and $2.84 \%$ for Cs, which one can consider within the experimental error bar. Thus it is confirmed from tables 2 and 3 that the presently calculated values of internal energy and entropy are in good agreement with experimental data as well as one of the best results among the other reported data [4]. This confirms the applicability of our model potential in the 
Table 2. Various contributions to the internal energy.

\begin{tabular}{|c|c|c|c|c|c|c|c|c|c|}
\hline \multirow{2}{*}{ Metal } & \multicolumn{2}{|c|}{$\begin{array}{l}E_{\text {elec }} \\
\times 10^{-3}(\mathrm{au})\end{array}$} & \multicolumn{2}{|c|}{$\begin{array}{l}E_{\text {ion }} \\
\times 10^{-3}(\mathrm{au})\end{array}$} & \multicolumn{2}{|c|}{$\begin{array}{l}E_{\text {elec-ion }} \\
\times 10^{-3}(\mathrm{au})\end{array}$} & \multicolumn{3}{|c|}{$\begin{array}{l}\text { Internal energy } \\
(E) \times 10^{-3}(\mathrm{au})\end{array}$} \\
\hline & Present & $\begin{array}{l}\text { Others } \\
{[4]}\end{array}$ & Present & $\begin{array}{l}\text { Others } \\
{[4]}\end{array}$ & Present & $\begin{array}{l}\text { Others } \\
{[4]}\end{array}$ & Present & \begin{tabular}{|l} 
Others \\
{$[4]$}
\end{tabular} & $\begin{array}{l}\text { Expt. } \\
{[25]}\end{array}$ \\
\hline $\mathrm{Na}$ & -81.70 & $\begin{array}{l}-81.61 \\
-81.61 \\
-81.61\end{array}$ & -211.48 & $\begin{array}{l}-212.9 \\
-211.92 \\
-210.16\end{array}$ & 62.95 & $\begin{array}{l}76.50 \\
72.57 \\
50.00\end{array}$ & -230.24 & $\begin{array}{l}-217.31 \\
-220.96 \\
-241.77\end{array}$ & -226.0 \\
\hline K & -80.04 & $\begin{array}{l}-79.89 \\
-79.89 \\
-79.89\end{array}$ & -169.28 & $\begin{array}{l}-169.03 \\
-168.39 \\
-166.41\end{array}$ & 59.12 & $\begin{array}{l}66.49 \\
58.47 \\
38.29\end{array}$ & -190.20 & $\begin{array}{l}-182.43 \\
-189.81 \\
-208.01\end{array}$ & -190.0 \\
\hline $\mathrm{Rb}$ & -78.57 & $\begin{array}{l}-78.41 \\
-78.41 \\
-78.41\end{array}$ & -157.94 & $\begin{array}{l}-156.77 \\
-156.49 \\
-151.45\end{array}$ & 57.66 & \begin{tabular}{|l|}
58.54 \\
53.37 \\
26.98
\end{tabular} & -178.86 & $\begin{array}{l}-176.64 \\
-181.53 \\
-202.88\end{array}$ & -180.0 \\
\hline Cs & -76.50 & $\begin{array}{l}-76.31 \\
-76.31 \\
-76.31\end{array}$ & -145.74 & $\begin{array}{l}-143.53 \\
-144.19 \\
-134.38\end{array}$ & 56.14 & \begin{tabular}{|l|}
56.33 \\
50.84 \\
14.97
\end{tabular} & -166.10 & $\begin{array}{l}-163.51 \\
-169.66 \\
-195.72\end{array}$ & -170.0 \\
\hline
\end{tabular}

Table 3. Various contributions to the entropy.

\begin{tabular}{|c|c|c|c|c|c|c|c|c|c|}
\hline \multirow{3}{*}{ Metal } & \multicolumn{9}{|c|}{ Entropy } \\
\hline & \multicolumn{2}{|c|}{$S_{\text {gas }} / k_{\mathrm{B}}$} & \multicolumn{2}{|c|}{$-S_{\eta} / k_{\mathrm{B}}$} & \multicolumn{2}{|c|}{$S_{\text {elec }} / k_{\mathrm{B}}$} & \multicolumn{3}{|c|}{$S / k_{\mathrm{B}}$} \\
\hline & Present & \begin{tabular}{|l|} 
Others \\
{$[4]$}
\end{tabular} & Present & $\begin{array}{l}\text { Others } \\
{[4]}\end{array}$ & Present & $\begin{array}{l}\text { Others } \\
{[4]}\end{array}$ & Present & $\begin{array}{l}\text { Others } \\
{[4]}\end{array}$ & \begin{tabular}{|l} 
Expt. \\
{$[25]$}
\end{tabular} \\
\hline $\mathrm{Na}$ & 11.222 & $\begin{array}{l}11.2238 \\
11.2238 \\
11.2238\end{array}$ & 3.9421 & $\begin{array}{l}.2284 \\
4.1400 \\
3.6523\end{array}$ & 0.0519 & $\begin{array}{l}0.0518 \\
0.0518 \\
0.0518\end{array}$ & 7.3317 & $\begin{array}{l}7.047 \\
7.136 \\
7.623\end{array}$ & 7.79 \\
\hline $\mathrm{K}$ & 12.6742 & $\begin{array}{l}12.6756 \\
12.6756 \\
12.6756\end{array}$ & 3.9421 & $\begin{array}{l}3.7968 \\
3.6037 \\
3.1211\end{array}$ & 0.0803 & $\begin{array}{l}0.0803 \\
0.0803 \\
0.0803\end{array}$ & 8.8123 & $\begin{array}{l}8.959 \\
9.152 \\
9.635\end{array}$ & 9.45 \\
\hline $\mathrm{Rb}$ & 14.0507 & $\begin{array}{l}14.0522 \\
14.0522 \\
14.0522\end{array}$ & 3.9421 & $\begin{array}{l}3.4692 \\
3.3929 \\
2.4472\end{array}$ & 0.0920 & $\begin{array}{l}0.0919 \\
0.0919 \\
0.0919\end{array}$ & 10.200 & $\begin{array}{l}10.67 \\
10.75 \\
11.69\end{array}$ & 10.35 \\
\hline Cs & 14.9486 & $\begin{array}{l}14.9501 \\
14.9501 \\
14.9501\end{array}$ & 3.9421 & $\begin{array}{l}3.1283 \\
3.2983 \\
1.8473\end{array}$ & 0.1076 & $\begin{array}{l}0.1076 \\
0.1076 \\
0.1076\end{array}$ & 11.114 & $\begin{array}{l}11.92 \\
11.75 \\
13.21\end{array}$ & 12.12 \\
\hline
\end{tabular}


Table 4. Contribution to the Helmholtz free energy.

\begin{tabular}{|c|c|c|c|}
\hline \multirow{2}{*}{ Metal } & \multicolumn{3}{|c|}{$\begin{array}{l}\text { Helmholtz free energy } \\
F \times 10^{-3}(\mathrm{au})\end{array}$} \\
\hline & Present & Others [4] & Expt. [25] \\
\hline $\mathrm{Na}$ & -238.9049 & $\begin{array}{l}-225.6262 \\
-229.3932 \\
-250.7787\end{array}$ & -235.2061 \\
\hline K & -200.6147 & $\begin{array}{l}-193.0176 \\
-200.6257 \\
-219.3965\end{array}$ & -201.1167 \\
\hline $\mathrm{Rb}$ & -190.9164 & $\begin{array}{l}-189.2497 \\
-194.2342 \\
-216.6951\end{array}$ & -192.2315 \\
\hline Cs & -179.239 & $\begin{array}{l}-177.5969 \\
-183.5460 \\
-211.3314\end{array}$ & -184.3233 \\
\hline
\end{tabular}

investigation of thermodynamic properties of liquid alkali metals. The investigations with the other liquid metals, alloys and metallic glasses are in progress [26].

\section{Acknowledgement}

The work is supported under the special assistance programme at the level of Departmental Research Support by the University Grants Commission, New Delhi, INDIA.

\section{References}

1. Godwal B.K., Sikka S.K., Chidamaram R. Equation of state theories of condensed matter up to about 10 Tpa. // Physics Reports, 1983, vol. 102, No. 3, p. 121-197.

2. Allawadi N.K. Equilibrium theories of simple liquids. // Physics Reports, 1980, vol. 57, p. 241.

3. Hafner J. Structure and thermodynamics of liquid metals and alloys. // Phys. Rev. A, 1977, vol. 16, p. 351-364.

4. Singh Sudhir, Singh R.N. Effect of core-ion potential on thermodynamic properties of liquid alkali metals and alloys. // Phys. Chem. Liq., 1994, vol. 27, p. 203-214.

5. Singh R.N., Sommer F. Thermodynamic and structural interpretations of the under cooled liquid metals. // Phys. Chem. Liq., 1994, vol. 28, p. 129-140.

6. Singh R.N., Singh V.N. Pseudopotential method for the thermodynamic properties of liquid alkali metals. // Phys. Chem. Liq., 1991, vol. 22, p. 235-243. 
7. Li D.H., Li X.R., Wang S. Variational calculation of Helmholtz free energies with applications to the $s p$-type liquid metals. // J. Phys. F: Met. Phys, 1986, vol. 16, p. 309-321.

8. Lai S.K., Matsuura M., Wang S. Variational thermodynamic calculation for simple liquid metals and alkali alloys. // J. Phys. F: Met. Phys, 1983, vol. 13, p. 2033-2051.

9. Ono S., Yokoyama I. Thermodynamic properties of liquid alkali metals using onecomponent plasma reference systems. // J. Phys. F: Met. Phys, 1984, vol. 14, p. 2909 2922.

10. Regnaut C. Thermodynamic and structure of liquid metals: the variational approach versus the optimized random phase approximation. // J. Phys. F: Met. Phys, 1986, vol. 16 , p. 295-308.

11. Lai S.K., Akinlade O., Tosi M.P. Thermodynamics and structure of liquid alkali metals from the charged-hard-sphere reference fluid. // Physical Review A, 1990, vol 41, p. $5482-5490$.

12. Akinlade O., Lai S.K., Tosi M.P. Thermodynamics and structure of liquid metals from the charged-hard-sphere reference fluid. // Physica B, 1990, vol. 167, p. 61-70.

13. Akinlade O. Thermodynamics and structure of liquid metals from the soft sphere reference fluid. // Phys. Stat. Sol. (b), 1992, vol. 169, p. 23-31.

14. Hausleitner C., Hafner J. Soft-sphere reference system in thermodynamic variational calculations. II: Liquid transition metals. // J. Phys. F: Met. Phys, 1988, vol. 18, p. $1025-1036$.

15. Ashcroft N.W. Electron-ion pseudopotential in metals. // Phys. Lett, 1966, vol. 23, p. $48-50$.

16. Heine V., Abarenkov I.V. A new method for the electronic structure of metals. // Phil. Mag., 1964, vol. 9, p. 451-465.

17. Singh R.N., Srivastava P.L. Model potential calculation of binding energy and compressibility of alkali metals. // Phys. stat. sol. (b), 1978, vol. 89, p. k13-k16.

18. Jani A.R., Gajjar P.N., Patel H.K. Susceptibility of some simple metals by local pseudopotentials. // Phys. stat. sol. (b), 1992, vol. 169, p. K105.

19. Avte R.S., Gajjar P.N., Jani A.R. Contribution of a point defect to the electrical resistivity of some polyvalent metals. // Phys. stat. sol. (b), 1993, vol. 176, p. K59.

20. Gajjar P.N., Thakore B.Y., Luhar J.S., Jani A.R. Residual resistivity due to vacancies in alkali metals. // Acta Phys. Pol. A, 1994, vol. 86, p. 369.

21. Ashcroft N.W., Langreth D.C. Structure of binary liquid mixtures. I. // Physical Review, 1967, vol. 156, No 3, p. 685-692.

22. Ashcroft N.W., Langreth D.C. Structure of binary liquid mixtures. II. Resistivity of alloys and the ion-ion interaction. // Physical Review, 1967, vol. 159, No 3, p. 500-510.

23. Harrison W.A. Pseudopotential in the Theory of Metals. New York, Benjamin, Inc., 1966.

24. Taylor R. A simple, useful analytical form of the static electron gas dielectric function. // J. Phys. F: Metal Phys, 1978, vol. 8, p. 1699-1702.

25. Hultgren R., Desai P.D., Howking D.T. Gleiser M., Kelly K.K., Wagman D.D. Selected Values of the Thermodynamic Properties of the Element and Alloys. Ohio, Am. Soc. Metals, Metal Park, 1973.

26. Gajjar P.N., Thakor P.B., Jani A.R. Thermodynamic properties of Na, K and NaK equiatomic alloy. - In: Proc. Second International Disordered-Systems Associates Society (INDIAS) Conference - INDIAS:2000. (to be published). 


\title{
Термодинамічні властивості рідких лужних металів
}

\author{
П.Б.Факор, П.Н.Гедджар, А.Р.Дженай
}

Університет ім. Сердара Пейтела, фізичний факультет

Валлабх Відянагар-388120, Гуджарат, Індія

Отримано 18 вересня 2000 р., в остаточному вигляді 13 грудня 2000 р.

Внутрішня енергія, ентропія та вільна енергія Гельмгольца рідких лужних металів (Na, K, Rb i Cs) вивчається в рамках підходу збурених псевдопотенціалів, що базується на варіаційній техніці Гіббса-Боголюбова. Для опису електрон-іонної взаємодії в рідких лужних металах застосовано локальний псевдопотенціал. Обмінні та кореляційні ефекти представлено з використанням запропонованої Тейлором функції, що враховує поправку на локальне поле. Отримані значення внутрішньої енергії, ентропії та вільної енергії Гельмгольца для рідких лужних металів чудово узгоджуються з експериментальними даними.

Ключові слова: внутрішня енергія, ентропія, вільна енергія Гельмгольца, псевдопотенціал

PACS: $65.50,71.15 . H$ 